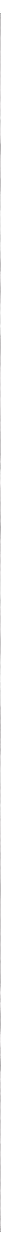

Christus zegent een Karolingische bisschop Sarcofaag van bisschop Adelochus (gest.823) in de Thomaskerk te Straatsburg.

Bron: Foto Nick Thompson. Via: http://www.fotopedia.com/items/flickr-3740879238 


\title{
Karolingische priesterexamens en het probleem van correctio op het platteland
}

\author{
Carine van Rhijn
}

Keizer Karel de Grote besloot rond het jaar 800 dat zijn hele

rijk grondig hervormd moest worden naar morele maatsta-

ven ontleend aan de Bijbel en kerkvaders. Lange tijd is ge-

dacht dat deze lovenswaardige plannen niet erg realistisch

waren, en daarom 'bleven steken' in kringen rond het hof.

Een serie nauwelijks bestudeerde teksten en manuscripten

werpen echter een ander licht op deze kwestie, en laten zien

dat de hervormingsidealen het uitgestrekte platteland wel

degelijk bereikten.

\section{Inleiding}

Tegen het einde van de achtste eeuw werd er aan het hof van Karel de Grote een hervormingsprogramma ontworpen dat de toestand in het Frankische Rijk aanmerkelijk moest gaan verbeteren. Om de plannen vorm te geven werd er uitvoerig vergaderd door de vorst en zijn graven, bisschoppen, abten en geleerden. De beslissingen werden opgetekend in zogeheten capitularia en rondgestuurd door het rijk. Speciale gezanten, de zogeheten missi, werden naar alle windstreken uitgezonden om ter plaatse te controleren of de besluiten ook werkelijk werden uitgevoerd, en om in te grijpen waar dat nodig was. Sleutelwoord in de operatie waren correctio (correctie) en emendatio (verbetering). Achter deze paraplu-begrippen ging een ambitieus project schuil, want volgens de hervormers mocht niets aan de correctio ontsnappen. Het ging hierbij om een integrale aanpak die zowel het wereldlijke als het religieuze besloeg - dit onderscheid werd in de vroege middeleeuwen niet gemaakt. Om deze manier van denken op waarde te schatten, is het belangrijk te weten dat de vroegmiddeleeuwse Franken zichzelf beschouwden als het nieuwe uitverkoren volk van God. Zij stonden onder leiding van een vorst die namens Christus op aarde regeerde, maar die tegelijkertijd verantwoordelijkheid verschuldigd was aan de Opperheerser voor het welzijn van het rijk. ${ }^{1}$ Dat de God van de Franken eiste dat Zijn uitverkoren volk zich naar de maatstaven van goed christendom gedroeg, sprak voor zich, net zoals de gedachte dat Hij onmiddellijk zou straffen wanneer de Franken Zijn eisen in de wind sloegen. Politiek en religie waren op deze manier twee kanten van dezelfde medaille. Ideeën over 'correct' Christendom waren dan ook cruciaal in de hervormingsplannen, want alleen wie de strenge, oudtestamentische God van de Franken op de juiste manier vereerde, kon hopen op Zijn steun en het voortbestaan van het rijk.

De Admonitio Generalis ('Algemene Aansporing') van 789, het document dat als startschot van de hervormingen wordt beschouwd, laat zien hoe breed de hervormers hun project opzetten. ${ }^{2}$ Er komt in deze tekst een ware baaierd aan onderwerpen voorbij, die zo ongeveer elk terrein van de vroegmiddeleeuwse wereld bestrijken. Zo is er aandacht voor de rechtvaardigheid van rechters, voor de vreedzame samenwerking tussen graven en bisschoppen, voor de standaardisering van maten en gewichten, maar ook voor het leven in kloosters, de kwaliteit van de lokale zielzorg en het gewenste gedrag van iedere Frankische christen.

\footnotetext{
Mary Garisson, 'The Franks as New Israel? Education for an identity from Pippin to Charlemagne' in: Yitzhak Hen en Matthew Innes red., The uses of the past in the early middle ages (Cambridge 2000) 114-61.

2 Admonitio Generalis (789), Alfred Boretius ed., Monumenta Germaniae Historia [MGH] Capitularia regum Francorum [Cap.] I (Hannover 1883) no.22. Algemeen over de Karolingische hervormingen: Giles Brown, 'Introduction: the Carolingian Renaissance' in: Rosamond McKitterick ed., Carolingian culture: emulation and innovation (Cambridge 1994) 1-52.
} 
De vraag was steeds 'hoe kunnen wij het goed doen in de ogen van God?', en het is dan ook niet verwonderlijk dat de teksten die inzicht gaven in deze vraag, zoals de Bijbel en de geschriften van de kerkvaders, een belangrijk referentiekader boden. Daar deed zich echter een probleem voor. In de loop van de voorgaande eeuwen waren deze teksten soms zo vaak overgeschreven dat er allerlei fouten in geslopen waren waardoor ze onbetrouwbaar werden. Het corrigeren van deze teksten had dan ook hoge prioriteit want, zo stelt de Admonitio Generalis, 'vaak willen mensen op de juiste manier tot God bidden, maar bidden ze verkeerd omdat de boeken niet kloppen. ${ }^{3}$ Verkeerd gebed, net als verkeerd begrip van het geloof, was niet alleen dom maar zelfs gevaarlijk. Wie, bijvoorbeeld, gedoopt werd met een doopformule vol fouten, zou niet gehoord worden door God en daarom nooit de hemel bereiken - evenmin als de priester die het ritueel op die manier verpestte. Hét grote probleem, zo realiseerden de hervormers zich, was dat onderwijs en daarmee kennis en geleerdheid nogal in het slop waren geraakt in de voorgaande generaties. Zelfs in de kloosters was het niveau van het Latijn zo ver gezakt dat men nota bene in het koningsklooster Fulda niet eens een foutloze brief aan de koning wist te schrijven - en hoe kon Karel de Grote er dan van uitgaan dat zulke monniken in staat waren foutloze en dus geldige gebeden namens hem naar God te sturen? ${ }^{4}$ Met het kennisniveau van de lokale bevolking was het ook niet al te best gesteld, aangezien er nogal wat aan te merken viel op de lokale priesters, dé lokale bronnen van kennis over goed geloof en goed gedrag.

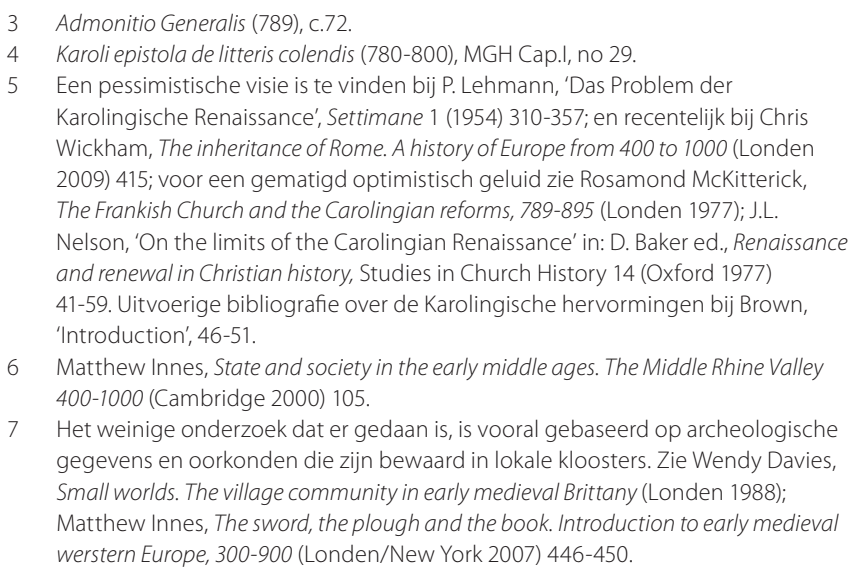

6 Matthew Innes, State and society in the early middle ages. The Middle Rhine Valley 400-1000 (Cambridge 2000) 105.

7 Het weinige onderzoek dat er gedaan is, is vooral gebaseerd op archeologische gegevens en oorkonden die zijn bewaard in lokale kloosters. Zie Wendy Davies, Small worlds. The village community in early medieval Brittany (Londen 1988); Matthew Innes, The sword, the plough and the book. Introduction to early medieval werstern Europe, 300-900 (Londen/New York 2007) 446-450.

De Karolingische hervormingen waren dus primair bedoeld om grote vooruitgang te boeken in de morele kwaliteit van de gehele bevolking, en om alles in het Frankische rijk te corrigeren volgens de normen van het 'correcte' christendom. De weg voorwaarts liep via een verbetering van kennis en onderwijs op ieder niveau, met de bijbel en de geschriften van de kerkvaders als uitgangspunt. Alleen door dit soort kennis, die mits ontdaan van fouten - zo zuiver werd geacht als de vroege kerk zelf, zouden de Franken, het Nieuwe Volk Israel, kunnen ontdekken hoe ze hun strenge, oudtestamentische God aan hun zijde konden houden. Het was daarmee een project dat alleen kon slagen als iedereen zijn steentje bijdroeg.

In theorie klinkt dit allemaal prachtig. De grote vraag die hier echter al heel lang bij wordt gesteld is in hoeverre deze plannen ooit helemaal ten uitvoer zijn gebracht, laat staan succes hadden buiten de kringen direct om het hof. Merkten de boeren hier nu ook iets van? Meestal wordt de kans dat dat het geval was niet erg groot geacht. ${ }^{5}$ Het uitgestrekte Karolingische rijk had weinig infrastructuur, er was trage communicatie en er waren nauwelijks middelen om voorschriften te implementeren. Zelfs al werden de capitularia naar kloosters, grafelijke hoven en bisschopssteden gestuurd, die dun gezaaid waren in een zeer uitgestrekt platteland, dan nog is het de vraag of pogingen tot lokale correctio ooit buiten hun directe invloedssfeer reikten. Waren de Karolingische hervormingen, met andere woorden, puur een eliteverschijnsel, of werd ook een deel van de boerenbevolking daadwerkelijk bereikt?

\section{Lokale gemeenschappen en lokale priesters}

Het Karolingische rijk bestond voornamelijk uit platteland, waarbinnen een gering aantal door aristocraten gedomineerde steden en grote kloosters functioneerden als verbindingspunten met het hof. ${ }^{6}$ De meeste mensen woonden in kleine boerengemeenschappen, soms op dagreizen afstand van het dichtstbijzijnde centrum. Er is buitengewoon weinig bekend over de situatie buiten deze centra; wie wil weten hoe het er in de dorpen en gehuchten van het rijk aan toe ging, moet het vooral hebben van de archeologie aangezien het overgrote deel van de bevolking ongeletterd was. ${ }^{7}$ De moeilijkheid bij het vinden 


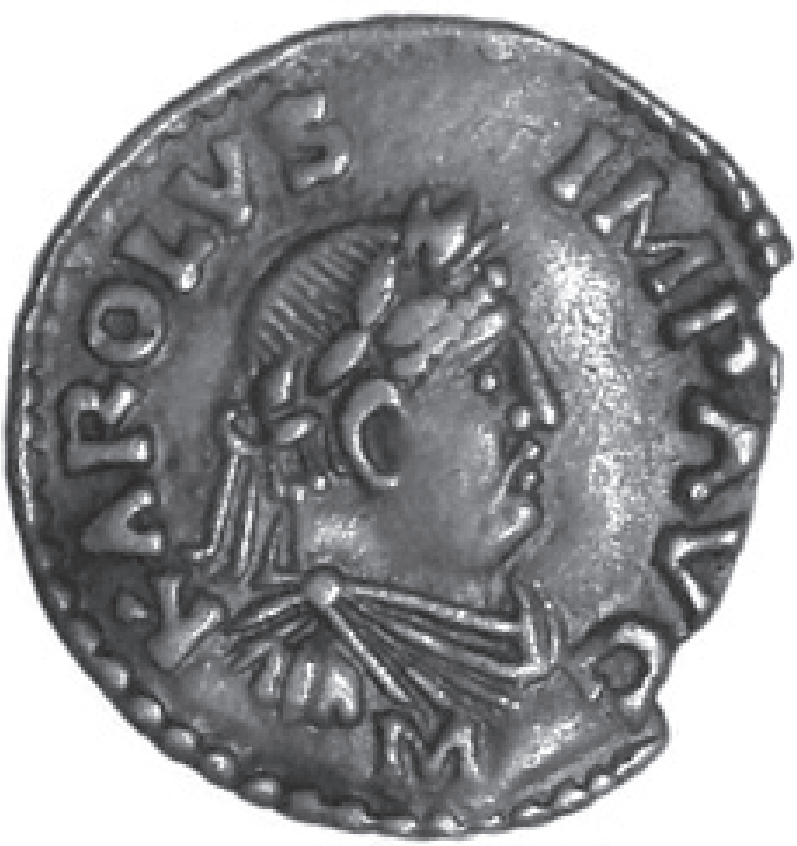

Munt met Karel de Grote afgebeeld als keizer [KAROLVS IMP AVG].

Bron: Foto door PHGCOM. Via: http://upload.wikimedia.org/wikipedia/commons/f/fb/Charlemagne_denier_Mayence_812_814.jpg

van eventuele sporen van lokale correctio zit hem dan ook in de eerste plaats in de bronnen.

Toch is er één uitzondering op deze regel, en dat is het materiaal over de priesters die in een groeiend aantal dorpen verantwoordelijk waren voor de zielzorg van de lekenbevolking. ${ }^{8}$ Hoewel er nog geen sprake was van duidelijk begrensde parochies in de moderne zin van het woord, nam vanaf de tweede helft van de achtste eeuw het aantal plattelandskerken hand over hand toe. In ieder geval in de meer centrale diocesen van het Frankische rijk, zo wordt aangenomen, bestond er rond het jaar 800 een tamelijk fijnmazig systeem van plattelandskerken. ${ }^{9}$ De priesters die deze kerken bestierden, waren waarschijnlijk meestal de enigen in het dorp die konden lezen en schrijven en enige vorm van opleiding genoten hadden. Daarnaast behoorden zij door hun vrije status en landbezit (iedere priester kreeg bij zijn benoeming een huis en wat land om van te leven) tot de lokale elite. ${ }^{10}$ Priesters vielen onder de directe verantwoordelijkheid van de bisschop, die erop toe moest zien dat zij hun taken naar behoren uitvoerden.

Deze plattelandspriesters kregen een spilfunctie binnen het programma van correctio en emendatio waarmee het hof wilde zorgen dat het gehele rijk een hoger moreel niveau bereikte. De gedachte was dat priesters bij uitstek geschikt waren om te zorgen dat hun lokale gemeenschappen zich bewust raakten van de noodzaak zich te gedragen volgens de principes van 'correct Christendom' zoals vastgelegd in onder andere de Admonitio Generalis. Via een getrapt systeem, dat van het hof, via de bisschop naar de plattelandspriester en ten slotte de lokale bevolking liep, kon althans in theorie de hele bevolking worden betrokken bij de hervormingsoperatie. De vraag is wederom in hoeverre dit ook echt werkte: kwamen deze instructies ook aan en hadden ze invloed op de kwaliteit van plattelandspriesters?

\section{Lokale correctio?}

Op het eerste gezicht is het niet onlogisch te veronderstellen dat pogingen tot correctio nauwelijks verder kwamen dan het hof en haar directe entourage van bisschoppen, abten en seculiere adel. Op het eerste gezicht maken de bronnen deze conclusie bijna vanzelfsprekend maken. Het overgrote deel van de manuscripten dat nog bestaat uit deze tijd komt immers uit kloosterbibliotheken, kathedraalarchieven of het hof, de eerder genoemde centra van het rijk - niet uit willekeurige dorpskerken. In deze centra vinden we de koninklijke capitularia en conciliebesluiten, normatieve teksten van hoog niveau waarin de idealen van correctio werden uiteengezet. Dit soort teksten was vaak aanwezig in de boekencollecties van bisschoppen of in kloosters en laat zien hoe hervormingsidealen verspreid raakten onder de direct betrokkenen. Eén niveau lager wordt het opeens een stuk stiller. Over de plattelandspriesters, die onder toezicht van deze bisschoppen moesten zorgen voor de lokale uitvoering van de correctio-idealen, weten we al een heel stuk minder; de lokale lekenbevolking zelf

8 Carine van Rhijn, Shepherds of the Lord. Priests and episcopal statutes in the Carolingian period (Turnhout 2007).

9 Zie Gabriel Fournier, 'La mise en place du cadre pariossial et l'évolution du peuplement', Cristianizzazione ed organizzazione ecclesiastica delle campagne nell'alto medioevo: espansione e resistenze, Settimane di Studio 28 (Spoleto 1982) 495-563; Christine Delaplace ed., Aux origines de la pariosse rurale en Gaule méridionale (IveIxe siècles) (Parijs 2005).

10 Wendy Davies, 'Priests and rural communities in East Brittany in the ninth century', Etudes Celtiques 20 (1983) 177-197; Carine van Rhijn, 'Priests and the Carolingian reforms: the bottlenecks of local correctio' in: Richard Corradini e.a. eds., Texts and identities in the early middle ages (Wenen 2006) 219-238. 
is voor historici vrijwel onzichtbaar. ${ }^{11}$ Er worden wel steeds meer handschriften herkend die ooit het bezit van lokale priesters waren, maar onderzoek daarnaar is er nog nauwelijks. ${ }^{12} \mathrm{Zo}$ kan het dus lijken dat hervormingsplannen als het ware 'bleven steken' in kringen van bisschoppen, abten en graven omdat we over deze groep nu eenmaal het best zijn geïnformeerd. Geen wonder dus dat historici daar in het verleden de conclusie aan hebben verbonden dat pogingen tot het corrigeren, reguleren en uniformeren van ieders geloof en gedrag niet veel verder reikten dan het hof en de adellijke kringen daar direct omheen, en ten hoogste een marginaal effect hadden op lokale omstandigheden. Nog steeds zijn er historici die deze mening zijn toegedaan ${ }^{13}$, maar er is inmiddels ook een groeiende groep onderzoekers die er anders over denken. Al in 1977 begon Rosamond McKitterick tegengas te geven, al had zij nog niet erg veel concreet bewijs dat er wel degelijk invloed van hervormingsidealen op het platteland te vinden valt. ${ }^{14}$

Inmiddels is met name door de gedetailleerde bestudering van handschriften en de publicatie van moderne tekstedities duidelijk geworden dat het mogelijk is om een stuk genuanceerder te zijn over deze kwestie en tot meer positieve conclusies te komen. ${ }^{15}$ Er zijn, bijvoorbeeld, teksten overgeleverd die een gedetailleerd beeld geven van de manier waarop bisschoppen vorm gaven aan de opdrachten tot hervorming die ze van hoog niveau kregen, al dan niet als resultaat van vergaderingen waar ze zelf bij waren. De zogenaamde 'Capitula Episcoporum', bisschoppelijke instructies voor de priesters van het eigen diocees, bijvoorbeeld, laten zien hoe tientallen bisschoppen probeerden om niet erg nauwkeurig omschreven hervormingsidealen te bewerken voor lokaal, priesterlijk gebruik. ${ }^{16}$ Deze geschriften bevatten niet alleen praktische instructies

11 Julia M.H. Smith, 'Religion and lay society' in: Rosamond McKitterick ed., The New Cambridge Medieval History ll (Cambridge 1995) 654-678.

12 Een uitzondering is Yitzhak Hen, 'Knowledge of canon law among rural priests: the evidence of two manuscripts of around 800', Journal of Theological Studies 50 (1999) 117-134

13 Wickham, The inheritance of Rome, 415, denkt dat het platteland niet of nauwelijks werd bereikt via de kerkelijke infrastructuur.

14 Zie McKitterick, The Frankish Church, die op 81 en 206-208 tegen dit idee in gaat.

15 Zie bijvoorbeeld Philippe Depreux, 'Ambitions et limites des réformes culturelles à l'époque carolingienne', Revue Historique 623 (2002/3) 721-753 aldaar 739; en Innes, The sword, the plough and the book, 474-478.

16 Peter Brommer, 'Capitula episcoporum'. Die bischöflichen Kapitularien des 9. und 10. Jahrhunderts. Typologie des sources 43 (Turnhout 1985); tekstedities in MGH Capitula Episcoporum I-III (Hannover 1984-1995). voor voorbeeldig priesterlijk gedrag, maar leerden de priesters ook wat zij, op hun beurt, moesten onderwijzen aan hun gemeenschappen van leken. Deze manier van werken laat goed zien hoe de hervormings-operatie in de praktijk vorm kreeg en werkbaar werd: de vorst en zijn raadgevers vaardigden de algemene principes uit, bisschoppen implementeerden die binnen hun eigen diocees door ze via lokale priesters naar het niveau van de dorpen en gehuchten te brengen. Op die manier werd, als alles goed ging, uiteindelijk de gehele bevolking bereikt.

Er hing in dit systeem veel af van de kwaliteit van lokale priesters, die verantwoordelijk werden gemaakt voor de cruciale laatste stap tussen bisschoppelijke instructies en de grote, sterk verspreide, plattelandsbevolking. Het was uiteindelijk door hun inspanningen als levende voorbeelden van het gewenste (christelijke) gedrag, maar ook als lokale zielzorgers, dat het Karolingische rijk gevuld zou moeten raken met 'correct' levende christelijke onderdanen. Bisschoppen werkten aan de kwaliteit van hun plattelandspriesters door ze aanwijzingen te geven, bijvoorbeeld in de vorm van de eerder genoemde bisschoppelijke statuten, die daarmee al een duidelijk teken zijn van het doordringen van hervormingsidealen tot op het niveau van individuele dorpen. Veel minder bekend zijn de zogenaamde priesterexamens, een relatief kleine groep teksten die ook ontstond op bisschoppelijke schrijftafels als gevolg van de Karolingische pogingen tot correctio. Deze teksten leveren interessante inzichten op, niet alleen over de reikwijdte van pogingen tot lokale hervormingen, maar ook over wat bisschoppen hierbij zowel belangrijk als haalbaar achtten. Nog beter dan de bisschoppelijke statuten kunnen deze examens laten zien dat het wel degelijk mogelijk is om enig inzicht te krijgen in lokale correctio en in de manier waarop priesters werden ingezet voor de hogere doelen van het hof. Daarom zal deze groep tekstjes in het hierna volgende de hoofdrol spelen: ze brengen ons dicht bij wat naar mijn mening als de kern van lokale hervormingspogingen kan worden beschouwd.

\section{Karolingische priesterexamens}

De Tsjechische abt en geleerde Ernst Vykoukal heeft in 1913 het eerste en tot nu toe enige artikel 
gepubliceerd over het examineren van priesters in de Karolingische periode. Zijn doel daarbij was het beschrijven van een aantal teksten en situaties waaronder examens mogelijk werden afgenomen. ${ }^{17}$ Vykoukal interpreteerde de examens en enige aanverwante teksten als een manier om de lokale clerus uit het moeras van de vroegmiddeleeuwse 'corruption morale affreuse' te bevrijden in tijden van 'anarchie dans le clergé'. ${ }^{18}$ Hij was wellicht iets te optimistisch in zijn overtuiging dat deze examens onmiddellijk overal met de regelmaat van de klok werden afgenomen en zo de kerk er weer bovenop hielpen, maar zijn idee dat priesterexamens samenhangen met de Karolingische hervormingen staat volgens $\mathrm{mij}$ nog steeds overeind. Er kan echter meer met dit materiaal worden gedaan dan het te beschrijven. Zo werpt het, bijvoorbeeld, interessant licht op de discussie over de lokale effecten van de Karolingische hervormingspogingen. Een kleine eeuw na het verschijnen van Vykoukal's artikel is er bovendien zoveel gebeurd op het gebied van het ontdekken van handschriften en het editeren van teksten, dat er meer examens bleken te bestaan dan hij kon weten. ${ }^{19}$

Het gaat mij hierna niet alleen om deze teksten zelf, maar ook om de implicaties van hun inhoud en om de handschriften waarin ze zijn overgeleverd. Wat dit alles laat zien is, kort gezegd, hoe er op een aantal plaatsen hard werd gewerkt aan correctio in lokale gemeenschappen, wat de achterliggende ideeën daarbij waren en hoe die wijzen op een groter lokaal effect van de beslissingen die aan het hof werden genomen dan wel is vermoed. De premisse hierbij is even eenvoudig als belangrijk, namelijk dat de examens - zoals alle vroegmiddeleeuwse teksten - geschreven (en overgeschreven) werden om aan een behoefte te voldoen en dat ze dus een direct doel dienden. Dit doel wordt in een aantal koninklijke capitularia uit de periode duidelijk genoemd, namelijk dat priesters niet geordineerd mochten worden voordat ze ondervraagd waren over hun kennis en vaardigheden. ${ }^{20}$ Dat de examens een direct produkt van deze vorstelijke beslissingen waren is duidelijk: een aantal begint met een citaat of een parafrase ervan ${ }^{21}$ of grijpt direct terug op het capitulare dat Karel de Grote in 802 speciaal aan het examineren van de clerus wijdde. ${ }^{22}$ Waar die vragen precies over gingen zal verderop worden uiteengezet, eerst volgt hier een kort overzicht van het materiaal om duidelijk te maken met wat voor soort teksten we hier te maken hebben. Wat is nu precies een priesterexamen?

Een Karolingisch priesterexamen bestaat uit een serie vragen (of onderwerpen voor vragen), soms met de modelantwoorden erbij, die gesteld werden aan lokale priesters door de bisschop of zijn representant. Ze gaan, kort gezegd, over de centrale componenten van het priesterschap zoals de viering van de mis en de uitvoering van sacramenten. De gelegenheid waarbij een dergelijk examen afgenomen kon worden was, voor zover we dat uit de examens zelf kunnen opmaken, bij de ordinatie van de priester of tijdens jaarlijkse bisschoppelijke visitaties. ${ }^{23}$ Het is goed mogelijk dat een paar van de overgeleverde priesterexamens niet meer dan een ingekorte versie zijn van iets dat zich in principe mondeling afspeelde. Twee heel summiere teksten, niet meer dan een lijstje onderwerpen in steekwoorden, lijken op deze manier ontstaan te zijn. ${ }^{24}$ Als uitgeschreven tekst kon zo'n examen ook een didactische functie hebben, of in een later stadium van priesterlijke educatie dienen als naslagwerk, zeker als de antwoorden erbij gegeven waren. Bij een aantal examens zijn zelfs andere teksten opgenomen die te maken hebben met hetgene dat een priester moest weten om zijn werk naar behoren te doen. Een goed voorbeeld is het manuscript Sankt Gallen, Stiftsbibliothek $40 .{ }^{25}$ Het derde deel van dit handschrift, dat dateert van kort na 800 , begint met een priesterexamen, dat gevolgd wordt door een hele serie teksten op basis waarvan een priester zijn taken

$$
\begin{aligned}
& 18 \text { d'histoire ecclésiastique XIV (1913) 81-96. } \\
& \text { Ibidem, } 81 \text { en } 96 . \\
& \text { Vykoukal kende ongeveer de helft van het materiaal waarop dit artikel is geba- } \\
& \text { seerd, maar hanteerde een lossere definitie. Om die reden besprak hij een aantal } \\
& \text { teksten, zoals een aantal capitularia, die naar mijn idee geen priesterexamens } \\
& \text { zijn. Zie: Vykoukal, 'Les examens', 93-96. } \\
& 20 \text { Zie bijvoorbeeld MGH Capitularia regum Francorum I, ed. A. Boretius (Hannover } \\
& \text { 1883), no. 19, c.4; no. 38, intro; no. 40, c.2; no. 112, c.35. } \\
& \text { De Interrogationes examinationis openen bijvoorbeeld met 'In palatio regis inven- } \\
& \text { tum habent ut presbiteri non ordinentur priusquam examinentur', een letterlijk citaat } \\
& \text { uit het Capitulare Missorum (803), c.2, MGH Capitularia regum Francorum I, no. } 40 . \\
& 22 \text { Dit is het Capitulare de examinandis ecclesiasticis (802), MGH Cap.reg. Francorum } \\
& \text { I, no 38, waarop de Capitula Frisingensia II direct, en de Capitula Frisingensial } \\
& \text { indirect teruggrijpen. } \\
& 23 \text { Vykoukal noemt niet minder dan zeven gelegenheden, maar alleen deze twee } \\
& \text { zijn duidelijk uit de teksten zelf te herleiden. } \\
& 24 \text { De Capitula Frisingensia I en II, beide in MGH Capitula Episcoporum III, ed. R. } \\
& \text { Pokorny (Hannover 1995) 204-5 en 210-211. } \\
& \text { http:///www.e-codices.unifr.ch/de/list/one/csg/0040 [24-02-2012]. }
\end{aligned}
$$$$
\text { oukal, 'Les examens du clergé paroissal a l'epoque Carolingienne, Revue }
$$ 
kon vervullen en de vragen uit het examen kon beantwoorden. Het is verder niet ongebruikelijk om de tekst van het doopritueel of een uitleg van de mis aan te treffen in hetzelfde handschrift als een priesterexamen, zoals bijvoorbeeld in het Noord-Franse handschrift Parijs, bibliothèque nationale lat $1012 .{ }^{26}$ Wie deze teksten beheerste, kon probleemloos antwoord geven wanneer de bisschop bijvoorbeeld wilde weten in hoeverre de kandidaat de doop-ordo kende én begreep, maar wist ook dat zijn kennis op niveau was. ${ }^{27} \mathrm{We}$ hebben hier dus te maken met een serie teksten die primair bedoeld waren als examen, maar daarnaast ook andere functies konden vervullen.

Tot nu toe zijn er acht priesterexamens uit de negende eeuw boven water gekomen, die overgeleverd zijn in totaal twintig handschriften uit de negende tot en met de twaalfde eeuw. ${ }^{28}$ Dat is, zelfs voor de vroege middeleeuwen, niet overweldigend veel, maar ook weer niet zo weinig dat we er niets mee kunnen. De examens zijn bijna allemaal anoniem, en dateren op één uitzondering na uit de vroegste jaren van de negende eeuw. Geografisch gezien is er meer spreiding: er zijn in die korte periode examens geschreven in een aantal belangrijke kerkelijke centra zoals Luik, Mainz, het klooster Sankt Gallen, en ook opvallend veel teksten en handschriften uit Beieren. Zes van de acht teksten, die dus verspreid over het Karolingische rijk werden geschreven tussen pakweg 800 en 810 , hangen inhoudelijk zo sterk samen dat het lijkt alsof de bisschoppelijke auteurs gezamenlijk besloten hadden om hun

26 Dit manuscript bevat naast het examen 'Primum omnium qualis' een doop-ordo, een 'expositio missam et symbolum', een bisschoppelijk statuut (de Capitula Parisiensia), een serie preken en canones bevat. Ph. Lauer ed., Catalogue général des manuscrits Latins I (nos 1-1438) (Parijs 1939) 362; Rudolf Pokorny ed. MGH Capitula episcoporum III (Hannover 1995) 23.

27 Zoals in het examen van Waltcaud van Luik, vraag 1: 'De ordine baptisterii, qualiter unusquisque presbiter scit vel intellegit [...]' MGH Cap.ep.I, 45.

28 Het gaat om de volgende handschriften: Albi Bibliothèque Municipale ms 38bis en 43; Barcelona Biblioteca Universitaria ms 228; Florence, Biblioteca Riccardiana ms 256; St Gallen, Stiftsbibliothek ms 40; Keulen, Dombibliothek ms 120; Laon, Bibliothèque Municipale ms 288; Madrid, El Escorial Q.III.10; München, Bayerische Staatsbibliothek mss clm 6324. clm 6325, clm 14461, clm 14727, clm 28135; Parijs Bibliothèque Nationale mss lat 1008, lat 1012, lat 3182, lat 8508 en lat 13092; Sélestadt, Bibliothèque Municipale132; Biblioteca Apostolica Vaticana ms pal. lat 485. De recent ontdekte tekst in Montpellier, Bibl.Interuniversitaire,Section Médecine 387 is hier buiten beschouwing gebleven.

29 Uitgegeven als MGH Capitula Episcoporum I-III. Zie Van Rhijn, Shepherds of the Lord, passim.

30 Theodulf I, c.8, MGH Capitula Episcoporum I, ed. Peter Brommer (Hannover 1984) 108-109.

31 Dit is het eerste statuut van Theodulf van Orléans, MGH Cap.ep. I, 73-142.

32 Een van de weinige expliciete vermelding staat in het Capitulum Remense, MGH Cap.ep. III, 152. examen op een bepaalde manier te schrijven. Het is goed mogelijk dat zij elkaar ontmoetten op een koninklijk concilie of tijdens een grote synode en hierover vergaderden, al hebben we daar verder geen bewijs voor.

Dat de eerste priesterexamens rond 800 verschenen is opvallend, want in diezelfde tijd begonnen bisschoppen ook een ander type teksten te schrijven met min of meer hetzelfde doel. Dit waren de al eerder genoemde bisschopsstatuten ('Capitula Episcoporum'), die de vorm kregen van naslagwerken over alles dat een priester moest weten, kunnen en in de praktijk doen. ${ }^{29}$ Sommige aanwijzingen zijn heel praktisch van aard en laten zien hoe goed gedrag onderbouwd wordt door kennis van de Bijbel:

We constateren regelmatig dat er in de kerk oogst en hooi ligt opgeslagen, en daarom willen we dat er overal nauwlettend voor wordt gezorgd dat er niets in een kerk word t bewaard behalve kerkelijke gewaden en altaargerei en boeken, zodat we, wanneer er toevallig dingen in de kerk gebeuren die daar niet thuishoren, niet van de Heer zullen horen 'Mijn huis moet een huis van gebed zijn, maar jullie maken er een rovershol van.' [Mat 21,13]

Dit soort statuten werd in de negende eeuw een groot succes, er zijn er tientallen geschreven die in flinke hoeveelheden handschriften zijn overgeleverd - van het meest populaire statuut zijn, bijvoorbeeld, meer dan veertig exemplaren bewaard uit de middeleeuwen..$^{31}$ De insteek van de statuten is echter fundamenteel anders dan die van de examens. Typisch voor een bisschopsstatuut is dat het het meest weg heeft van een practisch vade mecum waarin de nadruk wordt gelegd op uitleg en vriendelijke aansporing door de bisschop. Sommige statuten vermelden expliciet dat priesters zich aan deze voorschriften dienden te houden; over het algemeen wordt dit verondersteld maar niet met zoveel woorden vermeld. ${ }^{32}$ Net zo goed als iedere priester de canones (het kerkelijk recht) diende te kennen, moest hij ook op de hoogte zijn van de inhoud van zijn vak.

Heel anders is de toon in priesterexamens, waarin de duimschroeven een stuk strakker worden aangedraaid. Hier vinden we juist wel een sterke nadruk op het eisen en controleren van priesterlijke kennis - af en toe klinkt er zelfs 


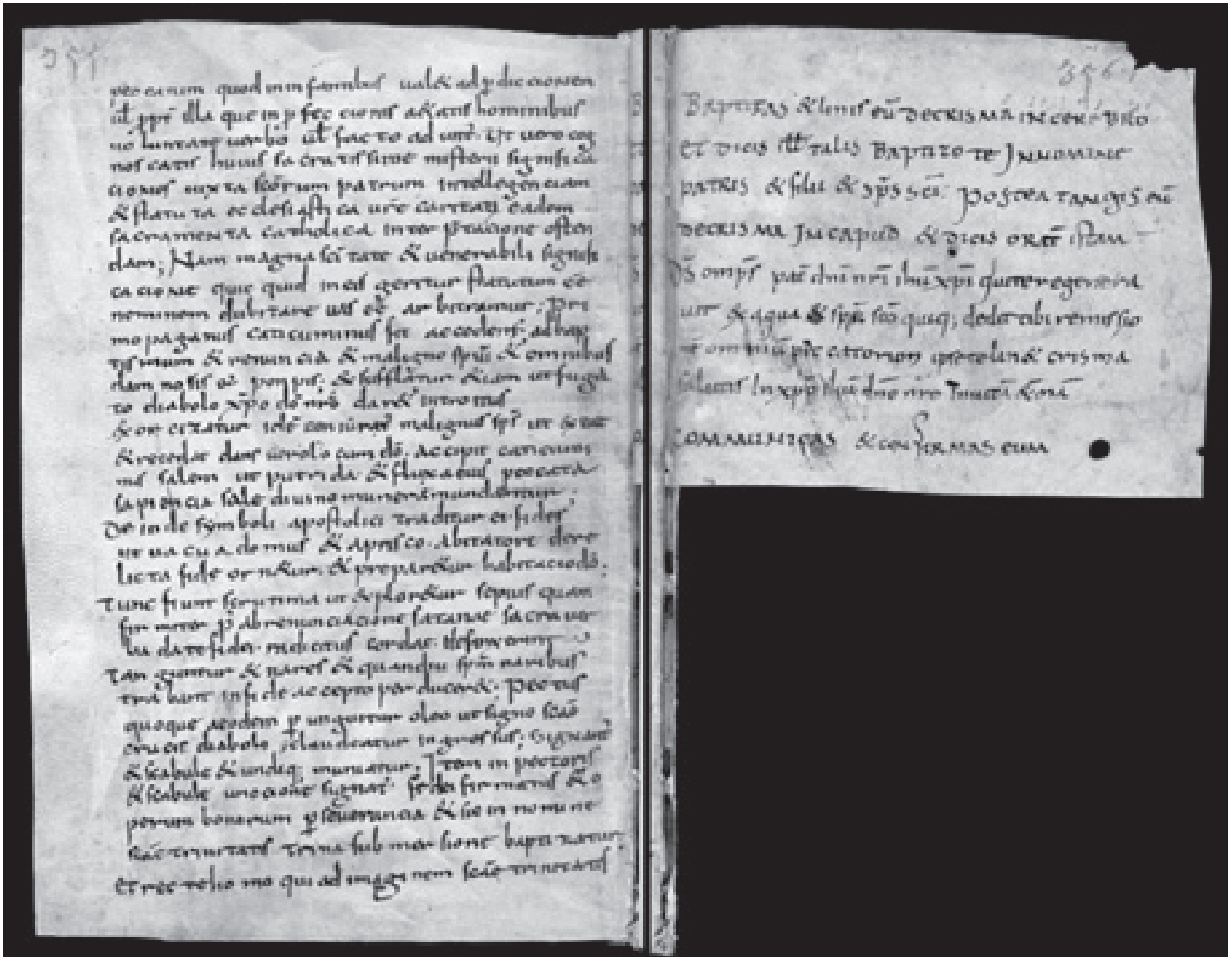

Karolingisch ivoren boekbeslag, met scenes uit het leven van de heilige Remigius,

en in het onderste paneeltje de doop van Clovis. Musée de Picardie, Amiens.

Bron: http://en.wikipedia.org/wiki/File:Mus\%C3\%A9e_Picardie_M\%C3\%A9di\%C3\%A9val_01.jpg

dreigende taal voor diegenen die de gevraagde kennis niet hebben of niet in de praktijk brengen. ${ }^{33}$ Waar bisschopsstatuten de gewenste kennis en vaardigheden op een rijtje zetten en toelichten, wordt deze in priesterexamens al bekend verondersteld en overhoord. Beide soorten teksten komen voort uit de wens om de kwaliteit van lokale zielzorg te bewaken en waar nodig te verhogen, maar de manier waarop individuele bisschoppen dat deden, verschilde. Het is hierbij ook interessant dat veel priesterexamens uit Beieren komen, terwijl er uit die contreien geen enkel handboek-achtig bisschoppelijk statuut bekend is. Kennelijk koos men daar in het begin van de negende eeuw voor de hands-on benadering van examineren, iets dat goed lijkt te passen bij de energieke pogingen tot correctio van de hervormingsgezinde aartsbisschop Arn van Salzburg. ${ }^{34}$ Het is daarbij zeker niet uitgesloten dat een bisschop of een priester beide soorten teksten goed kon gebruiken, een aantal handschriften met een priesterexamen bevat dan ook een of meer bisschoppelijke statuten. ${ }^{35}$

Het opmerkelijke verschil in hoeveelheden overgeleverde teksten en handschriften laat dui-

33 Bijvoorbeeld in het examen Primitus cum venerint, waarin aan het eind wordt gedreigd met ontheffing uit het priesterambt of langdurige opsluiting. Hartmann, 'Neue Texte', 394.

34 Getuige bijvoorbeeld zijn 'Instructio pastoralis', MGH Concilia 2.1 (Hannover 1906) no.22. Zie hierover: Raymond Étaix, 'Un manuel de pastorale de l'époque carolingienne (CIm 27152)', Revue Bénédictine 91 (1981) 105-130; Maximilian Diesenberger en Herwig Wolfram, 'Arn und Alkuin 790 bis 804: zwei Freunde und ihre Schriften', in: Meta Niederkorn-Bruck en Anton Scharer eds., Erzbischof Arn von Salzburg (Wenen/München 2004) 81-106 aldaar 97-100.

35 Twee voorbeelden uit de negende eeuw: Parijs, Bibliothèque Nationale lat 1012; Sélestat, Bibliothèque Municipale 132 [eerste deel]. 
delijk zien dat het systeem van werken met bisschopsstatuten populairder was dan de meer arbeidsintensieve methode van de priesterexamens. We hebben hier dus te maken met een beperkt verschijnsel, maar wel met een methode van lokale correctio die helemaal aan het begin van de negende eeuw werd uitgeprobeerd in een aantal centrale, belangrijke bisdommen. Aangezien ze vrijwel allemaal in dezelfde, korte tijd zijn ontstaan, kunnen we ze dus wel degelijk gebruiken om te onderzoeken wat lokale bisschoppen belangrijk vonden aan het kennisniveau van hun priesters en hoe zich dit verhoudt tot de idealen van de Karolingische hervormingen.

\section{De inhoud van priesterexamens}

Eén van de belangrijkste zaken die opvalt aan de priesterexamens is hoeveel kennis van verschillende teksten er wordt verondersteld. Een kleine inventarisatieronde leert dat er in zes van de acht examens expliciet naar dit soort 'boekenkennis' wordt gevraagd, en dat het daar minimaal vijf en maximaal ruim twintig teksten en tekstjes betreft. Twee van de examens pakken het anders aan, maar veronderstellen wel degelijk kennis van allerlei geschriften. In deze beide examens wordt bijvoorbeeld gevraagd hoe de priester de doop precies uitvoert en interpreteert, een vraag die zonder grondige kennis van een doop-ordo niet te beantwoorden is. ${ }^{36}$ De nadruk op dit soort kennis sluit uiteraard niet uit dat deze voor een deel mondeling opgedaan kon worden, bijvoorbeeld in het geval van psalmen en gebeden, maar over de gehele linie genomen zijn er ongetwijfeld manuscripten nodig geweest.

De teksten waarnaar in minstens de helft van de examens expliciet wordt gevraagd, zijn prak-

36 Daar komt bij dat de vraag wat de juiste manier van dopen was de gemoederen aan het keizerlijk hof in de vroege negende eeuw zodanig bezig hield dat enige flexibiliteit op dit punt niet erg waarschijnlijk is. Zie Susan A. Keefe, Water and the word. Baptism and the education of the clergy in the Carolingian empire, 2 delen (Notre Dame, 2002).

37 Bijvoorbeeld in Gerbald I, c.6, MGH Cap.ep I, p.18.

38 Er bestond bijvoorbeeld twijfel over anonieme boeteboeken die niet alleen elkaar, maar ook de Bijbel tegenspraken. Op het Concilie van Châlons (813) en het Concilie van Parijs (829) werden dit soort boeteboeken daarom verboden.

39 Steffen Patzold noemt dit de ontwikkeling van een 'Bildungskanon' vanaf de tweede helft van de achtste eeuw: Episcopus. Wissen über Bischöfe im Frankenreich des späten 8. bis frühen 10. Jahrhunderts, Mittelalter-Forschungen 25 (Ostfildern 2008) 122.

40 Helaas weten we uitermate weinig van de opleiding van plattelandspriesters, maar opleiding aan een kathedraalschool behoorde tot de mogelijkheden. Zie: Van Rhijn, Shepherds of the Lord, 175-178. tisch van aard en hebben direct te maken met de dagelijkse taken van elke priester. Het gaat hierbij om teksten als een doop-ordo, een boeteboek, canones (kanoniek recht), het evangelie, missen (in allerlei soorten), homelia (korte preken), de oratio dominicam (het onzevader), en het symbolum (het credo). We weten via bisschoppelijke statuten dat de laatste twee gebeden uit het hoofd gekend moesten worden door iedereen die gedoopt werd ${ }^{37}$, maar in de rest van de gevallen was er een boek nodig. Interessant hierbij is dat er vrijwel nooit gespecificeerd wordt om welke tekst het precies gaat als er twijfel mogelijk is: er bestonden veel verschillende boeteboeken, bijvoorbeeld, en allerlei homelia, om nog maar te zwijgen over alles wat er onder de parapluterm canones verstaan kon worden. Aangezien verschillende boeteboeken en canones elkaar nogal eens tegenspraken en er zeker in de tijd van de Karolingische hervormingen duidelijke ideeën bestonden over 'correcte' teksten, zal het hier niet gegaan zijn om willekeurig welke tekst uit de juiste categorie. ${ }^{38}$ Het lijkt waarschijnlijker dat de ondervraagde geacht werd precies te weten welk boeteboek, of welke lijst canones, dan wel welke doop-ordo de bisschop hier voor ogen had. Een dergelijk lijstje teksten wekt de indruk van een vastgesteld curriculum dat een priester volgens de lokale bisschop moest beheersen om zijn werk naar behoren te kunnen doen. Het valt uiteraard niet vast te stellen in hoeverre elke priester hier ook werkelijk aan gehouden werd, maar het gegeven dat er overeenkomsten bestaan in de samenstelling van deze lijsten in de verschillende examens suggereert centraal gemaakte afspraken en gedeelde ideeën over wat een goede scholing voor priesters behelste ${ }^{39}$; het feit dat er ook verschillen bestonden laat zien dat bisschoppen de precieze definiëring van wat elke priester moest weten, zelf konden invullen.

Het soms grote aantal bekend veronderstelde teksten, alsook het feit dat op cruciale punten precieze aanduidingen ontbreken, suggereert daarnaast niet alleen dat we het idee van half-geletterde plattelandspriesters in deze diocesen wellicht naar het rijk der fabelen moeten verwijzen, maar ook dat bisschoppen wel eens direct te maken kunnen hebben gehad met het opleiden van de priesters die in hun eigen diocees werkten. ${ }^{40}$ Als we de examens lezen als een logisch gevolg van de scholing die elke priester genoten had 
aan bijvoorbeeld de kathedraalschool, dan wordt de precieze functie van deze teksten al een stuk duidelijker. Wanneer het examen werd gedaan bij ordinatie, dan zou het om een laatste inspectie van de know-how van de kandidaat kunnen gaan voordat hij dit met een eigen leken-gemeenschap in de praktijk ging brengen. Ook als het examen gebruikt werd bij een bisschoppelijke visitatie lang nadat de priester gewijd was, lijkt kwaliteitscontrole de belangrijkste reden, wellicht om vast te stellen dat de benodigde kennis nog steeds paraat was. In beide scenario's is een dergelijke toets alleen maar zinvol als er ook reden was om te veronderstellen dat de kandidaat de gevraagde kennis in huis had en het examen ook werkelijk kon halen. Aangezien het verboden was om 'vreemde clerici', dat wil zeggen, geestelijken van buiten het eigen diocees, te ontvangen of te wijden $^{41}$, is het aannemelijk dat het hier om eigen kweek ging: mannen die binnen het diocees, of zelfs aan de kathedraal waren geschoold onder het toeziend oog van de bisschop zelf. Deze wist, daarom, dat de priester niet alleen in staat was de gevraagde teksten te lezen en te begrijpen, maar ook dat hij op enig moment in zijn opleiding met deze teksten in aanraking was gekomen en ze dus zou moeten beheersen. In sommige examens wordt bovendien niet alleen gevraagd naar kennis, maar ook naar begrip van de desbetreffende tekst, met het doel deze aan de lekenbevolking uit te kunnen leggen. ${ }^{42}$ Ook dit wijst op een situatie waarin een bisschop een examen schreef vanuit eigen kennis over degenen voor wie deze tekst gebruikt moest gaan worden en het kennisniveau dat hij van ze kon verwachten.

Een andere conclusie die, in het verlengde hiervan, aan de opvallende hoeveelheid gevraagde teksten kan worden verbonden (in totaal zijn het er ruim 25), is dat ze met grote waarschijnlijkheid ter plaatse voorhanden waren. Misschien was een deel alleen in de collectie van de kathedraal aanwezig, maar aangezien priesters er dan zeker tijdens hun scholing toegang toe hadden, is het idee dat correcte teksten daarmee 'bleven steken' op het niveau van bisschoppen dus misschien wat voorbarig. Het grootste deel van de gevraagde teksten had een priester echter nodig voor het uitvoeren van zijn pastorale taken, zoals allerlei geschriften voor de mis en de uitvoering van sacramenten. Hoewel het zeker niet gezegd is dat dit soort handschriften alle hoeken en gaten van het Karolingische rijk wisten te bereiken in deze periode, is een verband tussen het schrijven en gebruiken van priesterexamens enerzijds, en de aanwezigheid van de benodigde boeken anderzijds, naar mijn idee plausibel. Dat zou betekenen dat het bestaan van priesterexamens tegelijkertijd de beschikbaarheid van de daarvoor relevante teksten impliceert, niet alleen in de kathedraalbibliotheek, maar ook in de plattelandskerken zelf. Onderzoek van Carl Hammer heeft aangetoond dat er in ieder geval in Beierse plattelandskerken rond het jaar 800 inderdaad allerlei boeken aanwezig waren. ${ }^{43}$

De vraag die hierbij gesteld moet worden, is in hoeverre gebruik van priesterexamens en daarin genoemde teksten nu ook betekent dat idealen van correctio het platteland bereikten als gevolg van de Karolingische hervormingspogingen. Om hier antwoord op te vinden, is het om te beginnen nodig om de inhoud van de examens nader te onderzoeken en vast te stellen in hoeverre ze sporen bevatten van Karolingisch correctio-denken. Een tweede benadering zal zijn om te kijken in welke handschriftelijke context de examens zijn overgeleverd, aangezien dit zicht kan geven op het doel van het handschrift als geheel. Een aantal van deze handschriften bevat een cluster teksten die samen een 'correctio-dossier' vormen. Hoewel er nog erg weinig onderzoek is verricht naar dit soort handschriften, is het duidelijk dat er wel degelijk manuscripten bestaan die ooit het eigendom van een lokale priester zijn geweest. ${ }^{44}$

\section{Lokale correctio!}

Waar het gaat om de vraag in hoeverre correctioinitiatieven van het hof ook werkelijk bij 'het hele christelijke volk' belandden (al was het maar in bepaalde regio's) en daar tot uitvoering werden gebracht, zoals beoogd in bijvoorbeeld de Admonitio Generalis, levert het vinden van een antwoord hoe dan ook problemen op. Dat er naar aanleiding van deze initiatieven priesterexamens en bisschopsstatuten werden geschre-

41 Bijvoorbeeld in het capitulare van Soissons (744), c.5, MGH Cap.I no.12; Concilie van Ver (755), c.12, idem no.16; voortgezet onder Karel de Grote, bijvoorbeeld Admonitio Generalis (789), c.3, idem no.20.

42 Bijvoorbeeld Interrogationes examinationis c.6; Capitula Moguntiacensia c.1 en 2; Capitula Frisingensia II, c.2.

43 Carl Hammer Jr 'Country churches, clerical inventories and the Carolingian renaissance in Bavaria', Church History 49 (1980) 5-19.

44 Zie Hen, 'Knowledge of canon law'. 
ven door het diocesane episcopaat zegt op zichzelf nog niet zo veel. Sceptici zullen dan ook stellen dat het feit dat er zulke teksten werden geschreven, nog allerminst bewijst dat ze ook werkelijk gebruikt en geïmplementeerd werden. Desondanks vallen er wel degelijk duidelijke verbanden te ontdekken tussen de beslissingen van het hof in het kader van 'operatie correctio' en lokale initiatieven tot uitvoering daarvan. Wie bijvoorbeeld de Capitula de Examinandis Ecclesiasticis bestudeert, een koninklijke capitulare uit 802 dat over het kennisniveau van alle geestelijken gaat, zal grote inhoudelijke overeenkomsten zien tussen de daar opgenomen beslissingen over priesters en de priesterexamens. ${ }^{45}$

Er zijn meer van dit soort verbanden tussen teksten van het hof en priesterexamens, soms in de vorm van woordelijke citaten, vaak wat minder direct. Het geval van het Capitulare Missorum uit 803, koninklijke aanwijzingen voor de gezanten (missi) die de hervormingen ter plaatse moesten gaan begeleiden en controleren, is hierbij interessant. In deze tekst wordt gemeld 'dat priesters niet mogen worden geordineerd voordat ze zijn geëxamineerd'. ${ }^{46}$ Verdere aanwijzingen voor de inhoud van een dergelijke ondervraging worden er in dit Capitulare Missorum niet gegeven, maar dat was ook niet waar missi voor bedoeld waren. $\mathrm{Zij}$ dienden te controleren of deze examens werden afgenomen, het was aan de bisschoppen om de exacte inhoud vast te stellen. Precies deze uitspraak dient als de aanhef van één van onze priesterexamens, een duidelijk teken van de receptie van dit capitulare door een lokale bisschop. ${ }^{47}$ Het is daarom goed denkbaar dat het concilie in Aken waaruit dit capitulare is voorgekomen niet alleen de aanzet heeft gegeven voor het lokaal controleren of priesters wel geëxamineerd werden, maar ook voor het op schrift stellen van in ieder geval een deel van de vroege priesterexamens. Volgens de Annalen van Lorsch was dit Concilie van Aken een grote bijeenkomst waarbij veel bisschoppen aanwezig waren ${ }^{48}$, onder wie wellicht een aantal van de nu anonieme auteurs. Een dergelijk scenario zou

\footnotetext{
Capitula de examinandis ecclesiasticis (802), MGH Cap. I, no.38. 'Ut presbiteri non ordinentur priusquam examinentur', Capitulare missorum (803), c.2. Interrogationes examinationis, aanhef, MGH Cap.ep.III, p.214. Annales Laureshamenses (802), MGH SS I, ed. G. Pertz (Hannover 1826) 39. Daarvoor vinden we wel bepalingen voor de clerus als geheel, maar geen vermeldingen van priesters als afzonderlijke groep. Zie Van Rhijn, Shepherds of the Lord, 38-46.
}

verklaren waarom er heel vroeg in de negende eeuw 'opeens' priesterexamens werden geschreven in een aantal ver uit elkaar gelegen diocesen.

Wat waren nu de inhoudelijke hoofdpunten van deze examens, en kunnen we die wel echt verbinden aan ideeën over correctio en emendatio? Algemene voorschriften voor priesters in koninklijke capitularia beginnen met de vroegste Karolingische hofmeiers halverwege de achtste eeuw $^{49}$, dus de vraag of de priesterexamens zo'n vijftig jaar later oude thema's herhalen of juist met nieuwe eisen komen, is legitiem. Enig onderzoek leert dat de gestelde vragen in de priesterexamens voor het overgrote deel zonder precedent zijn op het punt van hun nauwkeurigheid. De capitularia stellen in het algemeen regels over priesterlijk gedrag, bijvoorbeeld tegen omgang met vrouwen en tegen het meedoen aan afkeurenswaardig 'lekengedrag' (jacht, drinkgelagen, frivole feesten et cetera). De allereerste melding van de wenselijkheid van het examineren van priesters voor hun ordinatie stamt uit een capitulare uit 742 , maar sporen van enig effect van deze bepaling zijn niet vast te stellen via andere teksten. Wel werd hij woordelijk herhaald door Karel de Grote in 769; pas na de Admonitio Generalis van 789 zien we echt aandacht ontstaan voor het kennisniveau van lokale priesters die wel is vast te stellen in andere teksten. Ook daar is de omschrijving van gewenste geleerdheid echter nog zeker niet zo nauwkeurig als in de priesterexamens en zijn de bepalingen over kennis gemengd met allerlei andere voorschriften. Desondanks is het duidelijk dat hier de fundamenten werden gelegd voor wat later, in Aken (802) heeft geleid tot verdere uitwerking van deze ideeën en wellicht tot het schrijven van de eerste priesterexamens. Hoewel de vragen in de examens dus wat betreft hun globale inhoud en achterliggende gedachten precedenten kennen uit de late achtste eeuw, is de gedetailleerdheid van de vragen, alsook de nadruk op (boeken)kennis van de examens wel nieuw. De examens zijn daarmee een direct product van correctio-denken en pogingen dit lokaal door te voeren, een idee dat alleen maar sterker wordt door een aantal andere inhoudelijke aspecten van deze teksten.

Eén van de meest in het oog springende eisen aan priesterlijke kennis, voor het eerst geformuleerd in het bovengenoemde capitulare van 802 en overgenomen in een aantal priesterexamens, is dat priesters hun Latijn zo goed beheersen 
dat ze allerlei soorten missen in zowel manlijke als vrouwelijke vorm, alsook in het meervoud konden verbuigen zonder fouten te maken. Het is belangrijk hierbij te bedenken dat deze eis in directe zin dan wel betrekking had op het kennisniveau van priesters, maar in wezen effect hadden voor de hele lekenbevolking. Het waren immers lekenzielen die door priesters op de juiste manier gehoed moest worden zodat ze ongeschonden het hiernamaals zouden bereiken, en zaken als de juiste doopformule en missen in correct Latijn werden daarvoor onontbeerlijk geacht. ${ }^{50}$ Datzelfde geldt voor de specifieke wens dat priesters de missen 'op de Romeinse manier' beheersten, en dat ze niet zo maar willekeurig welke preken kenden maar nadrukkelijk die 'van de orthodoxe vaders'. ${ }^{51}$ Een andere benadering is van meer theologisch-inhoudelijke aard en in dit verband zeker even interessant. Eén van de examens concentreert zich bijna exclusief op beheersing van de correcte doctrine: kandidaten moesten onder meer de Drie-Eenheid kunnen uitleggen, begrijpen hoe Christus mens en God tegelijk kon zijn, en in staat zijn de Wederopstanding inzichtelijk te maken voor het lokale lekenpubliek. ${ }^{52}$ De vooronderstellingen zijn in deze tekst niet wezenlijk anders dan in de andere priesterexamens, aangezien kennis van de daar genoemde teksten leidt tot de theologische inzichten die hier gevraagd worden.

Zeker even belangrijk in de context van lokale correctio is het feit dat veel examens benadrukken dat priesters niet alleen al deze kennis in huis moesten hebben, maar ook in staat moesten zijn deze over te brengen aan anderen, vaak ongeschoolde leken. Hier wordt eens te meer duidelijk dat priesters werden beschouwd als het doorgeefluik van kennis over het geloof aan de dorpsbewoners, en daarmee de laatste schakel vormden tussen het hof en de vele, vaak kleine lokale gemeenschappen. In de examens wordt vooral de nadruk gelegd op het overbrengen van het juiste geloof en het uitleggen van het evangelie. Het voorschrift dat priesters het credo en onzevader moesten kunnen uitleggen houdt waarschijnlijk verband met onderwijs over het geloof dat catechumenen moesten krijgen voordat ze gedoopt werden, aangezien deze twee gebeden samen een ultra-compacte versie vormen van de belangrijkste geloofsprincipes en daarmee de gewenste basiskennis voor iedere christen vormden.$^{53}$ Een ander belangrijk vehikel voor onderwijs aan eenmaal gedoopte christenen was de preek, en ook het systeem van biecht, boete en reconciliatie vereiste uitleg van allerlei aspecten van het geloof, dat veel verder reikte dan wat er in de kerk gebeurde maar direct betrekking had op ieders gedrag. ${ }^{54}$ Ook daar lag een didactische taak voor priesters, van wie werd verwacht dat ze een levend voorbeeld van goed christelijk gedrag waren. Op deze manier liepen 'boeken-kennis' en didactische vaardigheden als het ware in elkaar over, en wordt duidelijk dat het mes van de priesterexamens aan twee kanten sneed: ze dienden er niet alleen voor om te controleren of priesters zelf vakbekwaam waren, maar ook of ze hun kennis wisten over te brengen op degenen over wiens ziel ze waakten. Elementen van deze manier van denken waren er al voor het einde van de achtste eeuw, maar de combinatie van dit alles maakt de priesterexamens ook inhoudelijk tot een typisch produkt van het Karolingische correctio-programma. Dat deze idealen het niveau van lokale gemeenschappen bereikten in ten minste een aantal diocesen, lijkt daarom een reële conclusie.

\section{Priesterhandschriften}

Priesterexamens zijn overgeleverd in een aantal verschillende soorten handschriften, waaruit vaak kan worden afgeleid wat de compilator als het primaire nut van de tekst beschouwde. Wanneer zo'n examen, bijvoorbeeld, in een handschrift is opgenomen waar verder uitsluitend canoniek recht in staat, valt daaruit op te maken dat ook het examen zo werd geïnterpreteerd. Staat het examen tussen de didactische teksten (bijvoorbeeld leerdialogen, of verhandelingen over spelling en grammatica), dan valt daaruit op te maken dat het waarschijnlijk werd gebruikt in het onderwijs aan een kathedraal- of kloosterschool. Van beide gevallen zijn voorbeelden te vinden, maar de meeste en in ieder geval

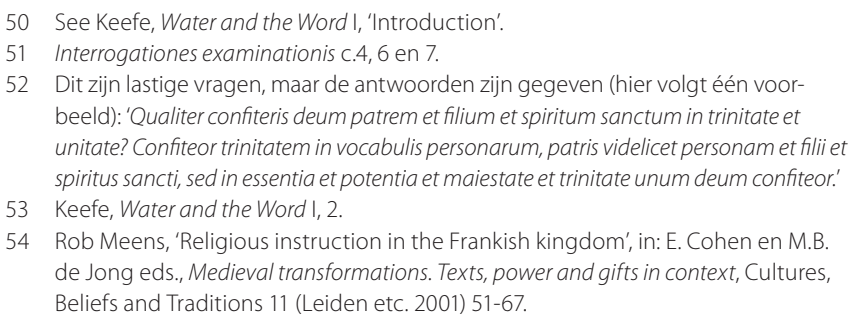




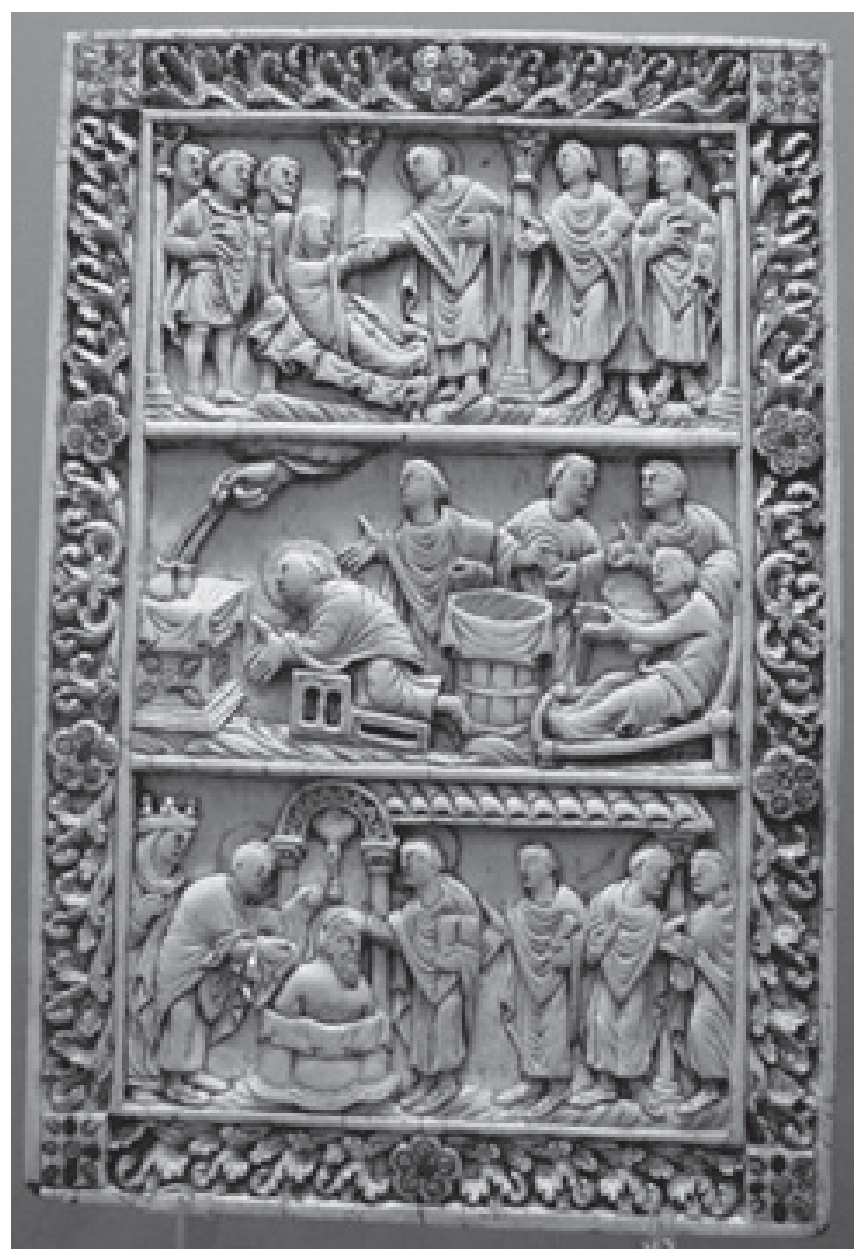

Laatste anderhalve pagina van het priesterhandschrift Sankt Gallen Stiftsbibliothek ms 40, beschreven in 'Karolingische hanepoten'.

Bron: Stiftsbibliothek Sankt Gallen/Codices Electronici Sangallenses

de vroegste handschriften met een priesterexamen zijn overwegend pastoraal van aard. Dit zijn vaak verzamelingen van soms tientallen teksten en tekstjes die van nut konden zijn bij het uitvoeren van priesterlijke taken en/of het op peil houden van hun kennis. Hierbij valt bijvoorbeeld te denken aan preken (die van - of toegeschreven aan - Augustinus waren erg populair), instructies voor de doop, een boeteboek, een computus waarmee de juiste Paasdatum kon worden berekend, uitleg over bijvoorbeeld de mis of het onzevader en een bisschoppelijk statuut. Dat dit manuscripten zijn die hoogstwaarschijnlijk ooit het bezit zijn geweest van een plattelandspriester, valt enkel af te leiden uit de inhoud. Allereerst bevatten deze handschriften teksten over taken die alleen iemand met een priesterwijding mocht uitvoeren (dus priesters en bisschoppen), zoals het afnemen van de biecht, de doop en het opdragen van de mis. Ondertussen vinden we niets wat met specifiek bisschoppelijke taken te maken heeft zoals het wijden van kerken, het uitvoeren van visitaties of het zegenen van altaren. De inhoud van dit soort pastorale handschriften was dus nauwkeurig toegesneden op de gebruiker, waarbij de rol van het priesterexamen daarbinnen veel weg heeft van een geheugensteuntje of een kort naslagwerkje. Het is goed mogelijk dat dit soort priesterhandschriften zelf een direct produkt zijn van de Karolingische hervormingen - voorbeelden van voor pakweg 780 zijn er voor zover ik weet niet of nauwelijks. Hoe zien dit soort manuscripten er nu uit?

Priesterhandschriften zijn vaak simpel uitgevoerde, kleine manuscripten ter grootte van een moderne zakagenda. Ze zijn in veel gevallen gemaakt van niet al te mooi perkament en soms geschreven in het vroegmiddeleeuwse equivalent van hanepoten - en regelmatig in enigszins wonderlijk Latijn. Dit verklaart ten dele het feit dat er zo weinig aandacht aan deze handschriften is besteed door wetenschappers: het zijn kleine, onooglijke boekjes met soms flinke gaten in het perkament (al dan niet netjes dichtgenaaid), folia van ongelijk formaat, scheef geschreven regels en gebruikssporen zoals vieze vingers en afgesleten hoekjes van het omslaan. Door dit soort karakteristieken staan ze helemaal aan het andere einde van het spectrum van de veel beter bestudeerde topstukken van de Karolingische periode: minder mooi dan dit komt het niet. Dit zijn ondertussen wel de handschriften waarmee lokale priesters werkten. Misschien hadden ze hun eigen exemplaar wel zelf samengesteld en geschreven op basis van bijvoorbeeld een bisschoppelijke boekencollectie. Gezien de kostbaarheid van perkament kunnen we er vanuit gaan dat er geen overbodige zaken in dit soort boekjes werden opgenomen. Dat betekent dat de inhoud direct nut had voor de gebruiker en daarom invloed had op de manier waarop deze zijn taken vervulde. Via dit soort priesterhandschriften kunnen we dus een idee krijgen van de manier waarop idealen van correctio plaatselijk gerecipieerd werden.

Zonder hier al te diep in te gaan op de details 
van deze handschriften, is het van belang om hier te wijzen op het feit dat de priesterexamens in deze handschriften bepaald niet de enige teksten zijn die sporen van correctio-denken vertonen. Hoewel het onderzoek hiernaar nog niet heel ver gevorderd is, is het nu al duidelijk dat ze vaak kleine dossiers bevatten van teksten die invloed van de hervormingsplannen vertonen. Naast categorieën van teksten die zelf een direct voortbrengsel van de hervormingen waren, zoals de examens zelf en de bisschoppelijke statuten, gaat het hier ook om de inhoud van al langer bestaande soorten teksten en de manier waarop die gebruikt werden in het kader van de nieuwe idealen. Een goed voorbeeld hiervan zijn preken, een genre dat al bestond sinds de vroege kerk. Dat priesterhandschriften preken bevatten, is op zichzelf niet erg verwonderlijk. Interessanter is dat bijna alle daar opgenomen preken zijn toegeschreven aan kerkvaders zoals Augustinus en Gregorius de Grote. Het is goed denkbaar dat dit een direct effect was van het voorschrift de preken van de 'orthodoxe vaders' te kennen ${ }^{55}$, in de bredere context van het algemene streven naar het gebruik van 'correcte' in plaats van dubieuze, anonieme teksten. Dat veel van de attributies in de handschriften niet kloppen is daarbij niet erg relevant, aangezien het er hier om gaat dat men dacht te maken te hebben met het authentieke werk. Op deze manier konden oude preken dus via nieuwe criteria geselecteerd worden en terecht komen in een priester-dossier dat volgens de hervormingsidealen was samengesteld. Iets dergelijks geldt voor de kleine collecties canoniek recht die in sommige priesterhandschriften zijn beland. Het gaat hier om bepalingen die soms honderden jaren oud waren, en juist vanwege hun ontstaan in de vroege kerk zuiver en relevant werden gevonden.

Een ander voorbeeld zijn alle expositiones (toelichtingen) en commentaren die we tegenkomen in de priesterhandschriften. Deze teksten geven uitleg, soms woord voor woord, over centrale teksten als het credo, het onzevader of (delen van) de mis. Er zit dus een duidelijke didactische kant aan deze teksten - niet alleen konden priesters in opleiding op deze manier diepere inzichten verwerven, maar ook konden zij deze teksten goed gebruiken om leken te onderwijzen. Priesters die dit soort teksten in hun bezit hadden, konden dus in één klap aan twee correctio-gerelateerde eisen voldoen: zorgen dat hun eigen kennis geen gaten vertoonde en het onderwijzen van leken. Op deze manier is de overlevering van priesterexamens direct gekoppeld aan de receptie van een breder scala aan correctio-gerelateerde teksten en tekstjes op het Karolingische platteland.

\section{Conclusie}

Het voorbeeld van de priesterexamens laat zien dat bisschoppen creatief waren in het verzinnen van manieren om het platteland te bereiken en het morele niveau daar te verbeteren. Het laat ook zien dat bisschoppen werkelijk bezig waren met kwaliteitscontrole van hun priesters, waarmee ze een belangrijke doelstelling van lokale correctio probeerden uit te voeren. Priesterexamens, die ook een didactische functie konden hebben, moeten we in deze samenhang beschouwen als een tamelijk kortlopend experiment dat zich voor zover bekend beperkte tot een klein aantal diocesen. Hoe kort en beperkt ook als verschijnsel, de examens geven als het ware een 'kijkje in de keuken' bij bisschoppen die zich rond het jaar 800 voor de ingewikkelde taak gesteld zagen om het religieuze leven en het morele niveau in hun diocees actief te verbeteren naar door het hof gestelde normen. In deze teksten wordt duidelijk waar de prioriteiten precies lagen, namelijk bij een uitvoerig pakket aan (boeken)kennis en vaardigheden die leidden tot lokale zielzorg van hoge kwaliteit en daarmee tot het uiteindelijk heil van de lokale gemeenschap. Dat deze idealen ook werkelijk gerecipieerd werden, valt te concluderen uit de samenstelling van de handschriften waarin de examens zijn overgeleverd. De lokale priesters die dit soort collecties teksten bezaten en beheersten, kunnen dan ook beschouwd worden als priesters 'Karolingische stijl': ze kenden hun Latijn goed genoeg, waren goed op de hoogte van allerlei vakinhoudelijke zaken en wisten die via onder meer preken over te brengen aan hun lekengemeenschap. Hoeveel van dit soort priesters er werkelijk rondliepen valt nauwelijks vast te stellen, maar dat ze er waren staat als een paal boven water.

Dr. Carine van Rhijn is universitair docent en onderzoeker middeleeuwse geschiedenis aan de Universiteit Utrecht. E-mail: c.vanrhijn@uu.nl 